\title{
Feedlot diets containing increasing starch levels and different feed additives changes cecal proteome profile involved on energy metabolism and inflammatory response of Nellore cattle
}

\section{Leone Campos Rocha ( $\sim$ leone.rocha@unesp.br)}

Sao Paulo State University Julio de Mesquita Filho: Universidade Estadual Paulista Julio de Mesquita Filho https://orcid.org/0000-0003-3715-0312

Andrey Sávio de Almeida Assunção

Sao Paulo State University Julio de Mesquita Filho: Universidade Estadual Paulista Julio de Mesquita Filho

\section{Renata Aparecida Martins}

Sao Paulo State University Julio de Mesquita Filho: Universidade Estadual Paulista Julio de Mesquita Filho

\section{Victor Valério de Carvalho}

DSM Nutritional Products

\section{Alexandre Perdigão}

DSM Nutritional Products

\section{Marília Afonso Rabelo Buzalaf}

University of São Paulo

Jiri Adamec

University of Nebraska-Lincoln

\section{Danilo Domingues Millen}

Sao Paulo State University Julio de Mesquita Filho: Universidade Estadual Paulista Julio de Mesquita Filho

\section{José Cavalcante Souza Vieira}

Sao Paulo State University Julio de Mesquita Filho: Universidade Estadual Paulista Julio de Mesquita Filho

\section{Pedro de Magalhães Padilha}

Sao Paulo State University Julio de Mesquita Filho: Universidade Estadual Paulista Julio de Mesquita Filho 
Keywords: Blend Essential Oils, Exogenous a-Amylase, Glucose, Monensin, Proteomic, Spectrometry Mass

Posted Date: September 9th, 2020

DOI: https://doi.org/10.21203/rs.3.rs-72268/v1

License: (c) (1) This work is licensed under a Creative Commons Attribution 4.0 International License. Read Full License 
Feedlot diets containing increasing starch levels and different feed additives changes cecal proteome profile involved on energy metabolism and inflammatory response of Nellore cattle Leone Campos Rocha ${ }^{1 *}$, Andrey Sávio de Almeida Assunção ${ }^{1}$, Renata Aparecida Martins ${ }^{1}$, Victor Valério de Carvalho ${ }^{2}$, Alexandre Perdigão ${ }^{2}$, Marília Afonso Rabelo Buzalaf ${ }^{3}$, Jiri Adamec ${ }^{4}$, Danilo Domingues Millen ${ }^{5}$, José Cavalcante Souza Vieira ${ }^{6}$, Pedro de Magalhães Padilha ${ }^{6}$

${ }^{1}$ São Paulo State University (UNESP), School of Veterinary Medicine and Animal Science,

9 Botucatu, São Paulo, Brazil.

$10{ }^{*}$ Correspondence: leone.rocha@unesp.br

\section{Abstract}

13 Background: Diets for feedlot cattle require higher energy density, thus contributing to the high rate

14 of fermentable carbohydrate. The use of feed additives is necessary to reduce possible metabolic

15 disorders. The objective of this study was to analyze the post-rumen effects of different levels of starch

$16(25,35$, and 45\%) and additives (Monensin, Blend of essential oil + exogenous $\alpha$-Amylase) in diets

17 for Nellore cattle feedlot. The cecum tissue proteome was separated by two-dimensional

18 polyacrylamide gel electrophoresis (2D-PAGE), and then, with the verification of differentially

19 expressed protein SPOTS, these were characterized by electrospray ionization mass spectrometry

20 (ESI-MS/MS).

21 Results: The expression of nine enzymes participating in the Steps of the glycolysis pathway was

22 verified, such as: Glyceraldehyde-3-phosphate dehydrogenase (GAPDH), Glyceraldehyde-3-

23 phosphate dehydrogenase like-17 protein, Triosephosphate isomerase (Step 1); Phosphoglycerate

24 mutase and Phosphoglycerate mutase 2 (Step 2); Alpha-enolase (ENO1), Beta-enolase (ENO3) and

25 Fructose-bisphosphate aldolase (ALDOB) (Step 4); and Pyruvate Kinase (PKM) (Step 5). There was

26 expression of three enzymes linked to catalytic activities participating in the synthesis of lactate from 
27 pyruvate: L-lactate dehydrogenase B, L-lactate dehydrogenase A chain and L-lactate dehydrogenase.

28 The ATP synthase subunit beta and ATP synthase subunit beta_mitochondrial participate in the

29 electron transport chain, producing ATP from ADP in the presence of a proton gradient across the

30 membrane. Due to the manipulation of diets, the expression of the Leukocyte elastase inhibitor protein,

31 associated with the inflammatory response.

32 Conclusions: The use of blends of essential oil associated with $\alpha$-amylase as a feed additive promoted

33 the greater expression of enzymes in the pathway of glycolysis and gluconeogenesis (and the absence

34 of proteins linked to inflammation (Leukocyte elastase inhibitor) in cecum tissues. On the other hand,

35 the increase in starch in the diets promoted a reduction in enzymes linked to carbohydrate degradation

36 with increased responses linked to inflammatory injuries.

38 Keywords: Blend Essential Oils, Exogenous $\alpha$-Amylase, Glucose, Monensin, Proteomic,

39 Spectrometry Mass

\section{Background}

Among the limitations to enhance meat production is the large energy requirement, which means that feedlot diets have a higher net energy demand (EL) [1]. Thus, increased starch in the diet, tests and physiological limits the digestive animals for the large amount of fermentable carbohydrates in the rumen and ruminal escape increased starch.

In the rumen, the fermentation of glucose from starch occurs, being converted mainly into volatile fatty acids (AGV) and lactate [2] which are metabolized in the liver and provide the greatest source of energy for ruminants $[3,4]$. However, the use of large amounts of starch can lead to disorders

49 and metabolic diseases due to the accumulation of organic acids in ruminal fluid, especially acidosis 50 and bloat [5]. Thus, feed additives that eliminate harmful processes of ruminal fermentation are 51 employed, such as sodium monensin, which is a polyester carboxylic ionophore used in growth and 
52 finishing diets [5]. in addition to acting bacteriostatically on gram positive ruminal bacteria, but with

53 the possible impact of residues on products of animal origin and microbial resistance [6]. Alternative

54 additives have shown the potential to replace monensin, such as blends of essential oil associated with

55 the exogenous enzyme $\alpha$-amylase, which has demonstrated gains in performance and carcass weight,

56 in addition to reducing hepatic abscesses and fecal starch in diets with high levels of starch [7-9].

57 With high levels of starch in the diet, the rate of passage and post-ruminal digestion increases

58 [5]. The rumen microbiota can digest around $70-80 \%$ of the starch consumed $[5,10-13]$, however, the

59 digestion and absorption of post rumen starch are partially impaired, as enzymatic digestion by

60 pancreatic $\alpha$-amylase in the duodenum is limited in the small intestine $[14,15]$. Another important

61 factor postulated by others is that glucose cannot be absorbed and transported in large quantities from

62 the lumen into the bloodstream due to insufficient levels of the glucose transporters SLGT1 and

63 GLUT2 $[5,16,17]$, which favors the escape of part of the starch to the large intestine and increases the

64 potential for digestion and use of this starch in the cecum. this favors the escape of some of the starch

65 to the large intestine and increases the potential for digestion and use of this starch in the cecum.

66 Therefore, feedlot diets that usually contain increased amounts of energy due to high levels of

67 concentrate inclusion [18] can cause excessive fermentation in the cecum, thereby contributing to the

68 metabolizable energy of ruminants $[19,20]$, however, it may generate inflammatory reactions in the

69 cecal epithelium. Feed additives that are able to increase the use of starch in the rumen, reducing the

70 escape of starch to the intestines, as well as lower starch levels in the diet of feedlot cattle, can avoid

71 the risk of cecal acidification.

72 Therefore, it is important to understand how the digestion and absorption sites act in the use of

73 starch in beef cattle. Due to the levels of starch in diets for cattle and their respective effects on the

74 extension of the gastrointestinal tract, associated with different feed additives, the objective of this

75 study is to map the proteome of the cecum of feedlot cattle, and to elucidate how protein expression

76 acts on metabolism in different nutritional strategies. 


\section{Material and Methods}

Animals, facilities, feeding and animal care

The field trial was conducted in at the feedlot facilities of the Innovation and Applied Science

81 Center of DSM Nutritional Products (I \& AS Beef Center) (Rio Brilhante, Mato Grosso do Sul, Brazil).

82 Nellore bulls $(\mathrm{n}=210)$ (Bos taurus indicus), with an average body weight of $\pm 380 \mathrm{~kg}$, from the grazing

83 system were used. The animals were randomly allocated to pens ( 7 animals/pen), with $12 \mathrm{~m}^{2}$ of

84 area/animal, drinking fountains and collective troughs $(50 \mathrm{~cm}$ linear/animal $)$. The program for

85 receiving the animals consisted of weighing, deworming and vaccinating according to the annual

86 prophylactic calendar. The animals were submitted to a pre-adaptation period of 10 days in order to

87 standardize their rumen population and adapt to the facilities and management. The diets were

88 formulated using the LRNS system (Large Ruminant Nutrition System, [21]), level 2, meeting the

89 nutritional requirements for daily weight gain between 1.5 and $1.7 \mathrm{~kg}$.day.animal ${ }^{-1}$. Feeding was done

90 twice a day at 8:00 am (40\% of the total) and 3:00 pm $(60 \%$ of the total), with constant water in the

91 automatic drinkers. The experimental diets were composed of bagasse sugarcane in nature, ground

92 corn, soybean hulls, cottonseed, soybean, mineral-vitamin core, urea and additives. The management

93 of the animals' adaptation period to the finishing diet was as follows: duration of 14 days, two diets

94 with $65 \%$ and $75 \%$ concentrate being provided for seven days each. From the $15^{\text {th }}$ day of the

95 experiment until slaughter of the animals, the finishing diet containing $85 \%$ concentrate was provided

96 (Table1). 
Table 1. Experimental diets containing increasing starch levels $(25,35$, and 45\%) and additives (Monensin, Blend of essential oil + exogenous $\alpha$-Amylase) in diets for Nellore cattle feedlot

\begin{tabular}{|c|c|c|c|c|c|c|c|c|c|}
\hline & \multicolumn{9}{|c|}{ Diets } \\
\hline \multirow{2}{*}{$\begin{array}{l}\text { Starch } \\
\text { level (\%) }\end{array}$} & & 25 & & & 35 & & & 45 & \\
\hline & $\begin{array}{c}\text { Adap } \\
.1^{1}\end{array}$ & $\begin{array}{c}\text { Adap } \\
.2^{2}\end{array}$ & $\begin{array}{c}\text { Finishin } \\
\mathrm{g}\end{array}$ & $\begin{array}{c}\text { Adap } \\
.1^{1}\end{array}$ & $\begin{array}{l}\text { Adap } \\
.2^{2}\end{array}$ & $\begin{array}{c}\text { Finishin } \\
\mathrm{g}\end{array}$ & $\begin{array}{c}\text { Adap } \\
.1^{1}\end{array}$ & $\begin{array}{c}\text { Adap } \\
.2^{2}\end{array}$ & $\begin{array}{c}\text { Finishin } \\
\mathrm{g}\end{array}$ \\
\hline & \multicolumn{9}{|c|}{ Ingredients $\left(\mathrm{g} \mathrm{kg}^{-1}\right)$} \\
\hline $\begin{array}{l}\text { Sugarcane } \\
\text { bagasse }\end{array}$ & 350 & 250 & 150 & 350 & 250 & 150 & 350 & 250 & 150 \\
\hline $\begin{array}{l}\text { Corn grain } \\
\text { grind }\end{array}$ & 300 & 330 & 360 & 300 & 400 & 500 & 300 & 470 & 640 \\
\hline $\begin{array}{l}\text { Soybean } \\
\text { meal }\end{array}$ & 90 & 55 & 20 & 90 & 65 & 40 & 90 & 75 & 60 \\
\hline $\begin{array}{l}\text { Whole } \\
\text { cottonseed }\end{array}$ & 60 & 80 & 100 & 60 & 80 & 100 & 60 & 80 & 100 \\
\hline $\begin{array}{l}\text { Soybean } \\
\text { hulls }\end{array}$ & 150 & 235 & 320 & 150 & 155 & 160 & 150 & 75 & 0 \\
\hline $\begin{array}{l}\text { Mineral } \\
\text { and } \\
\text { Vitamin } \\
\text { supplemen } \\
\text { t }\end{array}$ & 50 & 50 & 50 & 50 & 50 & 50 & 50 & 50 & 50 \\
\hline
\end{tabular}

\begin{tabular}{|c|c|c|c|c|c|c|c|c|c|}
\hline \multirow{2}{*}{$\mathrm{CP}^{3}$} & \multicolumn{9}{|c|}{ Nutrient Content (Dry matter, $\mathrm{g} \mathrm{kg}^{-1}$ ) } \\
\hline & 146 & 147 & 146 & 146 & 147 & 146 & 146 & 145 & 145 \\
\hline $\mathrm{TDN}^{4}$ & 660 & 680 & 690 & 660 & 690 & 730 & 660 & 720 & 770 \\
\hline $\mathrm{DPI}^{5}$ & 510 & 510 & 500 & 510 & 510 & 520 & 510 & 520 & 530 \\
\hline $\mathrm{NDF}^{6}$ & 437 & 424 & 412 & 437 & 382 & 330 & 437 & 316 & 252 \\
\hline peNFD $^{7}$ & 360 & 300 & 250 & 360 & 290 & 230 & 360 & 280 & 220 \\
\hline $\mathrm{Ca}^{8}$ & 7.7 & 7.5 & 7.3 & 7.7 & 7.5 & 7.3 & 7.7 & 7.6 & 7.5 \\
\hline $\mathrm{P}^{9}$ & 3.1 & 2.8 & 2.5 & 3.1 & 3.1 & 3.1 & 3.1 & 3.6 & 3.7 \\
\hline Starch & 209.5 & 230.8 & 254.6 & 209.5 & 284.0 & 355 & 209.5 & 372.8 & 458.0 \\
\hline $\mathrm{NE}$ & 2.40 & 2.44 & 2.48 & 2.40 & 2.51 & 2.63 & 2.40 & 2.62 & 2.77 \\
\hline \multicolumn{10}{|l|}{$\mathrm{Mcal} / \mathrm{kg}$} \\
\hline $\mathrm{DM}^{10}$ & & & & & & & & & \\
\hline
\end{tabular}

$104 \quad{ }^{1}$ Adap $1=$ Adaptation 1, 0-7 days; ${ }^{2}$ Adap 2 = Adaptation 2, 7 -14days, 14-89 days; ${ }^{3}$ Crude protein $(\mathrm{CP}) ;{ }^{4}$ Total digestible 105 nutrients (TDN); ${ }^{5}$ Digestible protein intake (DPI); ${ }^{6}$ Neutral detergent fiber (NDF); ${ }^{7}$ Physically effective neutral detergent 106 fiber (peNFD); ${ }^{8} \mathrm{Cá}$ lcium (Ca); ${ }^{9}$ Phosphor (P); ${ }^{10}$ Net energy (NE)

\section{Experimental design}

The factorial arrangement $3 \times 2$ was used, being the factors: STARCH LEVEL $(25 \times 35 \times 45 \%)$

110 and ADDITIVES (Monensin $\times$ Essential Oil Blend: CRINA ${ }^{\circledR}+$ Exogenous $\alpha$-Amylase: Rumistar ${ }^{\circledR}$ ).

111 Sodium monensin (Rumensin, Elanco Animal Health, Indianapolis, IN) used was included in the diet

112 at a dose of $26 \mathrm{mg} \mathrm{kg}^{-1}$ of dry matter. The blend of functional oils (CRINA RUMINANTS ${ }^{\circledR}$; DSM 
113 Nutritional products, Basel, Switzerland) containing thymol, eugenol, limonene and vanillin [22], and

114 the exogenous enzyme $\alpha$-amylase (RONOZYME RUMISTAR ${ }^{\mathrm{TM}}$; DSM Nutritional products, Basel,

115 Switzerland) were added to the diet at a dose of $90 \mathrm{mg} \mathrm{kg}^{-1}$ of dry matter, $560 \mathrm{mg} \mathrm{kg}^{-1}$ of dry matter, 116 respectively. The pens were distributed in a completely randomized block design, totaling 6 treatments 117 with 5 repetitions, totaling 30 experimental units. Thus, the distribution of treatments within the blocks

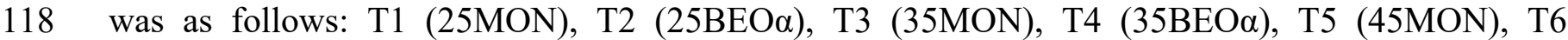
119 (45BEO $\alpha)$. According to the statistical model:

$$
Y_{i j k}=\mu+B_{k}+C_{i}+A_{J}+(C \times A)_{i j}+\varepsilon_{i j k}
$$

Where: $Y_{i j k}=$ Dependent variable; $\mu=$ Overall mean; $B_{k}=$ Block effect; $C_{i}=$ Concentrate; $A_{J}=$ Additive; $(C \times A)_{i j}=$ Interaction between concentrate and additive effects; $\varepsilon_{j i k}=$ Residual error.

\section{Sample Collection and preparation}

During the humane slaughter of animals, cecum samples were collected with an area of about

$4 \times 4 \mathrm{~cm}$, which were then washed with phosphate buffered saline (PBS), transferred to $15 \mathrm{ml}$ polypropylene bottles and placed in liquid nitrogen $\left(-196^{\circ} \mathrm{C}\right)$ for later protein extraction. The pen was considered the experimental unit, so a pool of samples was made from the homogenization of cecal tissue of the same treatment, wherein three animals per experimental unit were considered (totaling 15

131 animals/pool).

Extraction, precipitation and quantification of proteins

During the protocol, different extraction solutions were tested (buffer solution Tris- $\mathrm{HCl} \mathrm{pH}$ 1358.50 with protease inhibitors Leupepetin and Phenyl Methyl Sulfonyl Fluoride - PMSF, Tris- 
137 PMSF, with ultrapure water in the presence of protease inhibitors). The buffer which showed the beset results for protein extraction was ultrapure water.

To extract the protein fraction, the tissue was macerated with a mortar and pestle in the presence 140 of liquid nitrogen. The extracting solution was added in a proportion of $1 \mathrm{~g} / 1 \mathrm{~mL}$ (tissue/ultrapure 141 water), and then homogenized with an OMMI-BEAD RUPTOR4 cell disruptor (Kennesaw, Georgia, 142 United States) with 3 cycles of 30 seconds. They were subsequently separated into protein extracts and 143 supernatant after refrigerated centrifugation $\left(-4^{\circ} \mathrm{C}\right)$ with an UNIVERSAL 320R HETTICH 144 (Tuttlingen, Baden-Württemberg, Germany Thus, the proteins were precipitated in 80\% (v/v) acetone 145 (J.T. Baker, Phillipsburg, New Jersey, United States), using $300 \mu \mathrm{L}$ of supernatant and $600 \mu \mathrm{L}$ of $80 \%$ 146 acetone. The samples were stored at $2^{\circ} \mathrm{C}$ for 1.5 hours and then centrifuged at $14,000 \mathrm{rpm}$ for 30 147 minutes; the supernatant was discarded and the protein pellet was solubilized in $1 \mathrm{~mL}$ of $0.50 \mathrm{~mol} \mathrm{~L}^{-1}$ 148 NAOH (Merck, Darmstadt, Germany). Protein concentrations were determined by the Biuret method 149 [23] using an analytical curve with a concentration range from $0-100 \mathrm{~g} \mathrm{~L}^{-1}$ of standard bovine albumin solution (Acros Organics, NJ, United States) at the concentration $100 \mathrm{~g} \mathrm{~L}^{-1}$.

Electrophoretic separations of protein fractions using $2 D-P A G E$

For isoelectric focusing, about $375 \mu \mathrm{g}$ of proteins was applied to the strips; the sample was resolubilized with a solution containing $7 \mathrm{~mol} \mathrm{~L}^{-1}$ urea, $2 \mathrm{~mol} \mathrm{~L}^{-1}$ thiourea, $2 \%$ CHAPS $(\mathrm{m} / \mathrm{v})(\mathrm{GE}$ Healthcare , Uppsala, Sweden), ampholytes $\mathrm{pH} 3$ to 10 at $0.5 \%$ (v/v) (GE Healthcare, Uppsala, 156 Sweden) and $0.002 \%$ bromophenol blue (GE Healthcare, Uppsala, Sweden), in addition to $2.8 \mathrm{mg}$ 157 DTT (USB, Cleveland, Ohio, USA). Approximately $900 \mu \mathrm{L}$ of mineral oil was added at room temperature for 12 hours to rehydrate the strips. After this period, the strips were added to the 159 EttanTMIPGphorTM3 isoelectric focusing system (IEF) (GE Healthcare, Uppsala, Sweden). The 160 electrical voltage used was established by the protocol described by Braga et al. (2015). At the end of 161 focusing, the strip was balanced in two stages lasting 15 minutes each. At first, using $10 \mathrm{ml}$ of solution 
162 containing $6 \mathrm{~mol} \mathrm{~L}^{-1}$ urea, 2\% SDS (w/v), 30\% glycerol (v/v), $50 \mathrm{mmol} \mathrm{L}{ }^{-1}$ Tris- $\mathrm{HCl}(\mathrm{pH} 8.8), 0.002 \%$

163 bromophenol blue (w/v) and 2\% DTT (w/v), to keep the proteins in their reduced forms $[24,25]$. In the

164 second stage, a solution with a similar composition was used; however, DTT was replaced with $2.5 \%$

$165(\mathrm{w} / \mathrm{v})$ iodoacetamide, to obtain alkylation of the thiol groups of the proteins and thereby prevent

166 possible reoxidation. After the strip balance steps, the second dimension of the electrophoretic process

167 (SDS-PAGE) was submitted. The strip was applied to a $12.5 \%(\mathrm{w} / \mathrm{v})$ polyacrylamide gel previously

168 prepared on a glass plate $(180 \times 160 \times 1.5 \mathrm{~mm})$. The gel was placed next to the strip, with a piece of

169 filter paper containing $6 \mu \mathrm{L}$ of a molar mass standard (GE Healthcare, Uppsala, Sweden), with proteins

170 of different molar masses ( $\beta$-phosphorylase $(97.0 \mathrm{kDa})$, albumin $(66.0 \mathrm{kDa})$, ovoalbumin $(45.0 \mathrm{kDa})$,

171 carbonic anhydrase $(30.0 \mathrm{kDa})$, trypsin inhibitor $(20.1 \mathrm{kDa})$ and $\alpha$-lactalbumin $(14.4 \mathrm{kDa})$. The strip

172 and filter paper were sealed with $0.5 \%$ agarose solution $(\mathrm{w} / \mathrm{v})$, to ensure contact with the

173 polyacrylamide gel. The race program was then applied at 100 volts for 30 minutes, and a further 250

174 volts for 2 hours. After the run period, the gels were immersed in a fixative for 30 minutes containing

$17510 \%$ acetic acid (v/v) and 40\% ethanol (v/v); soon after, the proteins were revealed using the colloidal

176 Coomassie dye (USB, Cleveland, Ohio, USA) for $72 \mathrm{~h}$ and then removed by washing with deionized 177 water [24-27].

178 The gels obtained were scanned and their images analyzed using the image processing program

179 ImageMaster 2D Platinum 7.0 (GeneBio, Geneva, Switzerland), which allows the isoelectric points 180 and the molecular masses of the separated proteins to be estimated, and the number of SPOTS obtained 181 in gel electrophoresis to be calculated. Three replicates of each gel run were used to evaluate the 182 reproducibility of each protein SPOT obtained in the replicates of the gels, by overlaying the image 183 from one gel over the other, using the image treatment program [24-27].

184 Protein identification by mass spectrometry (ESI MS)

The protein spots were characterized by ESI-MS after being subjected to tryptic digestion and 186 the elution of peptides according to the methodology described by [28]. The aliquots of the solutions 
187 containing the peptides were analyzed to obtain the mass spectra through the nanoAcquity UPLC 188 system coupled to the Xevo G2 QTof mass spectrometer (Waters, Milford, MA, USA). The 189 identification of proteins was performed by searching in database UniProt (2020) with the Bos taurus 190 species. After the identification of the proteins, their sequences were analyzed by the FASTA software 191 OMICSBOX (BLAST2GO) and thus categorized by their molecular function, biological processes 192 and biochemical activities with Gene Ontology (GO). The same sequences were used to analyze 193 metabolic pathways using the Kyoto Encyclopedia of Genes and Genomes function (KEGG 194 parthways), making it possible to map the expressions of proteins encoding enzymes found in the 195 database.

\section{Statistical analysis}

The fixed effects analyzed were STARCH LEVEL AND ADDITIVE in a factorial design;

199 thus, the comparison between groups was by means of contrasts in order to verify differentially 200 expressed protein SPOTS. The images were analyzed using ImageMaster Platinum software version 201 7.0, which establishes correlation (matching) between groups. For this correlation, the 3 replicates of 202 gels were used comparing volume, distribution, relative intensity, isoelectric point and molecular mass 203 for analysis of variance (ANOVA) considering significance to determine the differentially expressed 204 protein SPOTS. Figure 1 describes the chronology and execution of the activities carried out. 


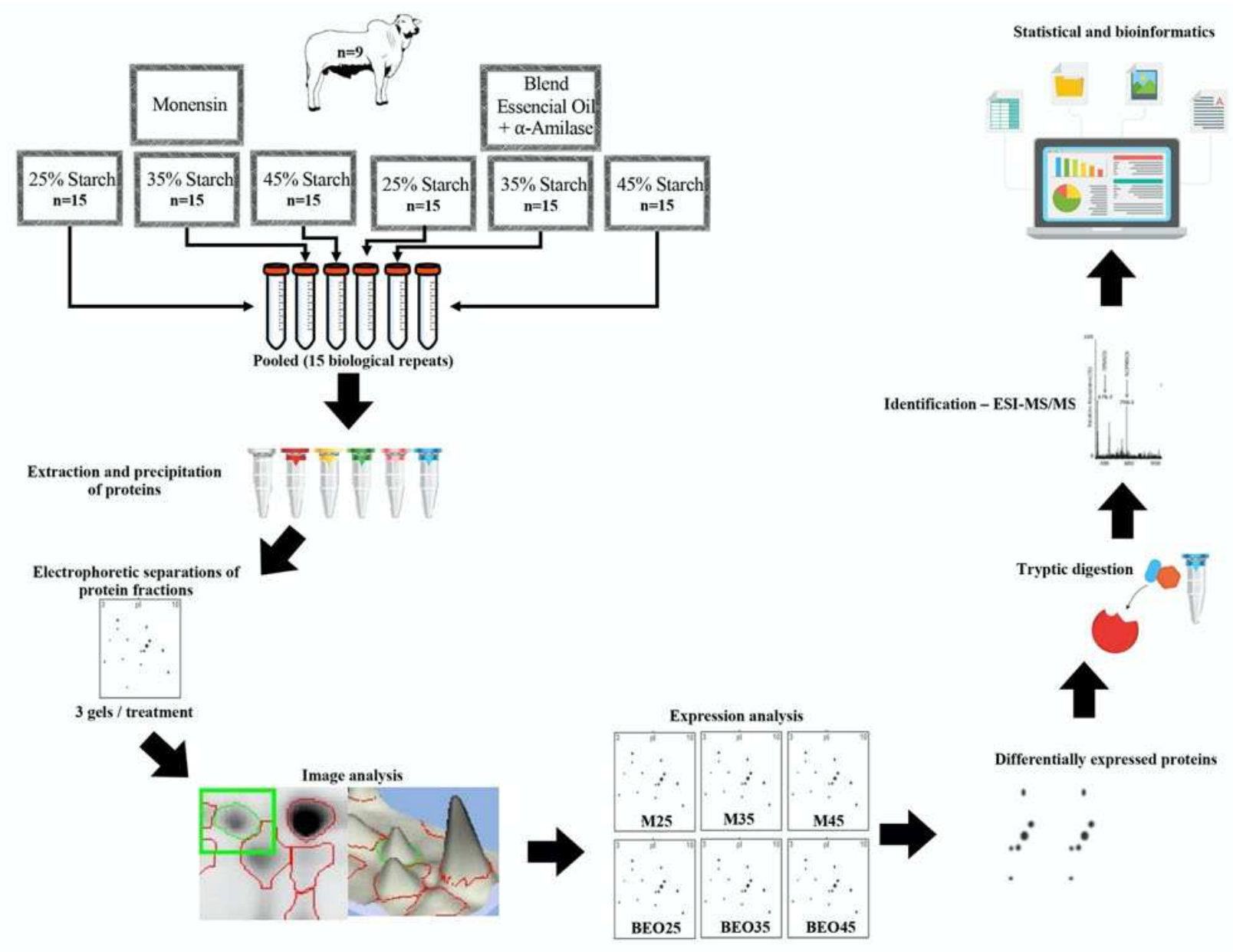

Figure 1. Graphical abstract

208 Results and Discussion

209 Image analysis and SPOTS expression

210 In the "Workspace", Classes (Groups) were created to analyze differences in protein

211 expression; for that, the analysis of variance (ANOVA) tests the hypothesis $\left(\mathrm{H}_{\theta}\right)$ that the expressed

212 SPOTS are identical (as shown in supplementary material). When testing all classes, protein SPOTS

213 were differentially expressed, as described in Table 2. 
216 Table 2. Differentially expressed SPOTS in Nellore beef cattle cecum fed with diets containing 217 increasing starch levels $(25,35$, and 45\%) and additives (Monensin, Blend of essential oil + exogenous $218 \alpha$-Amylase)

\begin{tabular}{|c|c|c|c|c|c|c|c|c|c|}
\hline \multirow{2}{*}{ SPOT (n) } & \multicolumn{3}{|c|}{$\mathrm{MON} \times \mathrm{BEO}^{*}$} & \multicolumn{3}{|c|}{$\mathrm{MON}^{*}$} & \multicolumn{3}{|c|}{ BEO* } \\
\hline & $25 \times 25$ & $35 \times 35$ & $45 \times 45$ & $25 \times 35$ & $35 \times 45$ & $25 \times 45$ & $25 \times 35$ & $35 \times 45$ & $25 \times 45$ \\
\hline $\mathrm{Up}$ & 9 & 3 & 7 & 14 & 3 & 8 & 5 & 0 & 1 \\
\hline Down & 11 & 16 & 5 & 6 & 28 & 4 & 10 & 6 & 13 \\
\hline+ & 10 & 59 & 14 & 22 & 65 & 35 & 34 & 16 & 27 \\
\hline$\varnothing$ & 37 & 11 & 14 & 81 & 19 & 42 & 18 & 8 & 16 \\
\hline Total & 67 & 89 & 40 & 125 & 115 & 89 & 67 & 30 & 57 \\
\hline
\end{tabular}

$219 * P \leq 0.05$;UP: Up-regulated SPOT; Down: Down-regulated SPOT; +: SPOT present in the first group in relation to 220 the second; $\varnothing:$ SPOT absent in the first group in relation to the second

223 functions and cellular component.

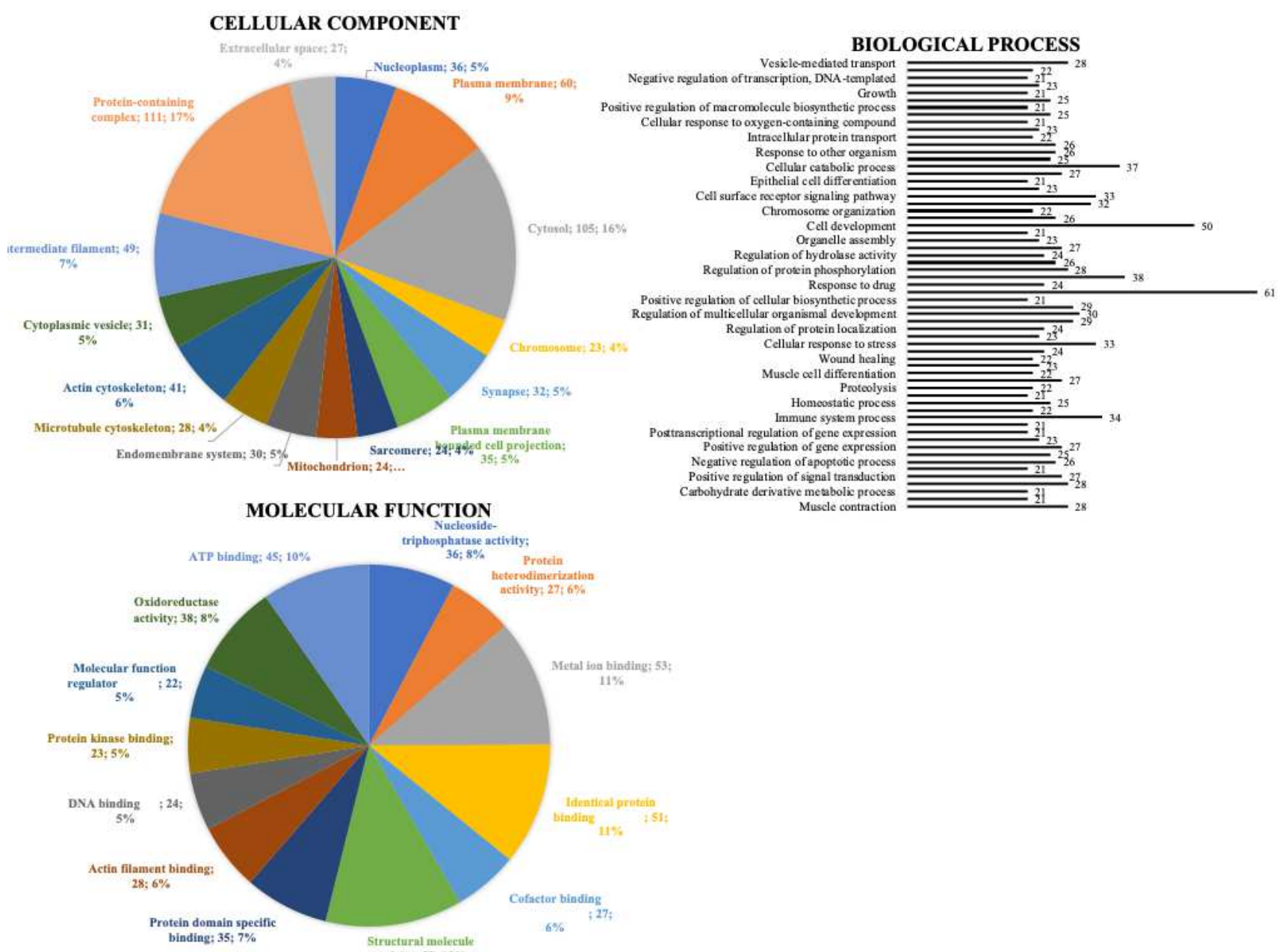

Figure 2. Classification of the proteins sequences found in beef cattle cecum proteome using OMICSBOX software analysis (Blast2GO). 
The differentially expressed SPOTS were characterized from mass spectrometry, after the

232 identification was standardized considering the highest Score Protein, $\mathrm{pI}$ and molecular mass (MM)

233 closest to the theoretical and experimental results. Among the proteins identified, 15 were addressed

234 as functional for the purpose of the study, which involve energy metabolism and inflammatory

235 response. Table 3 shows the differentially expressed protein profile in the cecum of Nellore beef cattle 236 under different levels of starch and feed additives.

Table 3. Protein profile differentially expressed in Nellore beef cattle cecum fed with diets containing increasing starch levels $(25,35$, and $45 \%)$ and additives (Monensin, Blend of essential oil + exogenous $\alpha$-Amylase) using ESI-MS/MS

\begin{tabular}{|c|c|c|c|c|}
\hline Protein & Access & Score & $\begin{array}{c}\mathrm{pI} / \mathrm{MM} \\
\text { theoretical (Da) }\end{array}$ & $\begin{array}{c}\mathrm{pI} / \mathrm{MM} \\
\text { experimental } \\
\text { (Da) }\end{array}$ \\
\hline \multicolumn{5}{|c|}{ Glucose and energy metabolism } \\
\hline Alpha-enolase & Q9XSJ4 & 1783.3310 & $6.37 / 47326.13$ & $6.70 / 56906$ \\
\hline Beta-enolase & Q3ZC09 & 440.2993 & $7.60 / 47096.01$ & $6.43 / 48539$ \\
\hline Triosephosphate isomerase & Q5E956 & 193.3130 & $6.45 / 26689.51$ & $7.24 / 25458$ \\
\hline L-lactate dehydrogenase B & Q5E9B1 & 4599.0320 & $6.02 / 36723.64$ & $6.37 / 39211$ \\
\hline $\begin{array}{c}\text { L-lactate dehydrogenase A } \\
\text { chain }\end{array}$ & P19858 & 1327.3960 & $8.12 / 36597.64$ & $6.37 / 39211$ \\
\hline Pyruvate Kinase & A5D984 & 98.4805 & $7.96 / 57948.91$ & $5.9 / 57613$ \\
\hline $\begin{array}{c}\text { Fructose-bisphosphate } \\
\text { aldolase }\end{array}$ & A6QLL8 & 1850.8330 & $8.45 / 39436.12$ & $6.37 / 39211$ \\
\hline Phosphoglycerate mutase & $\mathrm{F} 1 \mathrm{~N} 2 \mathrm{~F} 2$ & 427.2343 & $9.01 / 28699.04$ & $6.37 / 39211$ \\
\hline Phosphoglycerate mutase 2 & Q32KV0 & 413.5597 & $8.99 / 28685.05$ & $6.37 / 39211$ \\
\hline L-lactate dehydrogenase & F1MK19 & 70.7983 & $5.72 / 36724.58$ & $6.37 / 39211$ \\
\hline $\begin{array}{c}\text { Glyceraldehyde-3-Phosphate } \\
\text { dehydrogenase }\end{array}$ & P10096 & 11907.1000 & $8.51 / 35868.09$ & $8.12 / 29321$ \\
\hline $\begin{array}{c}\text { Glyceraldehyde-3-phosphate } \\
\text { dehydrogenase like-17 } \\
\text { protein }\end{array}$ & Q9XSN4 & 1934.1340 & $9.22 / 11514.31$ & $9.70 / 26577$ \\
\hline $\begin{array}{l}\text { ATP synthase subunit beta } \\
\text { mitochondrial }\end{array}$ & P00829 & 533.0471 & $5.15 / 56283.53$ & $5.49 / 47920$ \\
\hline ATP synthase subunit beta & A0A452DII8 & 533.0471 & $5.47 / 62225.55$ & \\
\hline \multicolumn{5}{|c|}{ Inflammatory response } \\
\hline Leukocyte elastase inhibitor & Q1JPB0 & 300.0084 & $5.70 / 42235.75$ & $5.70 / 38338$ \\
\hline
\end{tabular}


Proteins associated with glucose metabolism and energy synthesis (Table 3) and

243 macromolecules involved in the degradation of carbohydrates linked to the glycolytic pathway,

244 gluconeogenesis and oxidative phosphorylation were detected in cecal tissue. The expression of nine

245 enzymes participating in the Steps of the glycolysis pathway was verified, such as: Glyceraldehyde-3-

246 phosphate dehydrogenase (GAPDH), Glyceraldehyde-3-phosphate dehydrogenase like-17 protein,

247 Triosephosphate isomerase (Step 1); Phosphoglycerate mutase and Phosphoglycerate mutase 2 (Step

248 2); Alpha-enolase (ENO1), Beta-enolase (ENO3) and Fructose-bisphosphate aldolase (ALDOB) (Step

249 4); and Pyruvate Kinase (PKM) (Step 5). There was expression of three enzymes linked to catalytic

250 activities participating in the synthesis of lactate from pyruvate: L-lactate dehydrogenase B, L-lactate

251 dehydrogenase A chain and L-lactate dehydrogenase. The ATP synthase subunit beta and ATP

252 synthase subunit beta_mitochondrial participate in the electron transport chain, producing ATP from

253 ADP in the presence of a proton gradient across the membrane.

254 Due to the manipulation of diets, the expression of the Leukocyte elastase inhibitor protein,

255 associated with the inflammatory response, was verified (Table 3); this plays an essential role in

256 regulation of the innate immune response, inflammation and cellular homeostasis, and mainly acts to

257 protect cell proteases released into the cytoplasm during stress or infection.

258

259

260

Table 4. Expression values (ANOVA, $P \leq 0.05$ ) in beef cattle cecum protein profile fed starch levels $(25,35$ and $45 \%)$ and additives (Monensin and Blend Essential Oil $+\alpha$-Amylase)

\begin{tabular}{|c|c|c|c|c|c|c|c|c|c|}
\hline \multirow[b]{2}{*}{ Protein } & \multicolumn{3}{|c|}{$\mathrm{MON} \times \mathrm{BEO} \alpha$} & \multicolumn{3}{|c|}{ MON } & \multicolumn{3}{|c|}{$\mathrm{BEO} \alpha$} \\
\hline & $\begin{array}{c}25 \times 2 \\
5\end{array}$ & $\begin{array}{c}35 \times 3 \\
5\end{array}$ & $\begin{array}{c}45 \times 4 \\
5\end{array}$ & $\begin{array}{c}25 \times 3 \\
5\end{array}$ & $\begin{array}{c}35 \times 4 \\
5\end{array}$ & $\begin{array}{c}25 \times 4 \\
5\end{array}$ & $\begin{array}{c}25 \times 3 \\
5\end{array}$ & $\begin{array}{c}35 \times 4 \\
5\end{array}$ & $\begin{array}{c}25 \times 4 \\
5\end{array}$ \\
\hline \multicolumn{10}{|c|}{ Glucose and energy metabolism } \\
\hline Alpha-enolase & $+/ \varnothing$ & NS & 1,55 & $+/ \varnothing$ & $-1,48$ & $+/ \varnothing$ & 1,65 & NS & $+/ \varnothing$ \\
\hline Beta-enolase & $\varnothing /+$ & NS & 1,55 & $\varnothing /+$ & $-1,48$ & $\varnothing /+$ & NS & NS & NS \\
\hline $\begin{array}{l}\text { Triosephosphate } \\
\text { isomerase }\end{array}$ & $-3,55$ & $-2,55$ & NS & $+/ \varnothing$ & -2.39 & NS & NS & NS & $-1,84$ \\
\hline $\begin{array}{c}\text { L-lactate } \\
\text { dehydrogenase }\end{array}$ & $\varnothing /+$ & NS & $-1,47$ & $\varnothing /+$ & NS & NS & NS & NS & NS \\
\hline $\begin{array}{c}\text { L-lactate } \\
\text { dehydrogenase B }\end{array}$ & $\varnothing /+$ & NS & NS & NS & NS & NS & NS & NS & NS \\
\hline
\end{tabular}


L-lactate

dehydrogenase $\mathrm{A}$

chain

Pyruvate Kinase

$\varnothing /+\quad$ NS NS

NS $\varnothing /+\quad N S$

$-2,54 \quad$ NS

NS

Fructose-

bisphosphate

aldolase

Phosphoglycerat

$$
\text { e mutase }
$$

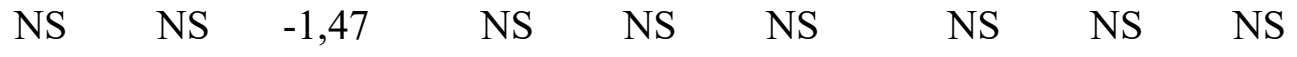

Phosphoglycerat

e mutase 2

Glyceraldehyde-

3-phosphate

dehydrogenase

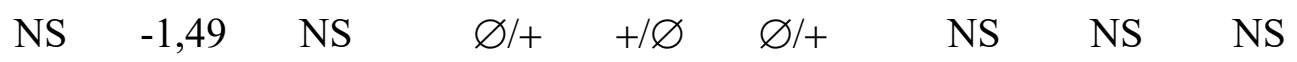

Glyceraldehyde-

3-phosphate

dehydrogenase

NS $\quad+\varnothing \quad$ NS $\quad \varnothing /+\quad+/ \varnothing \quad \varnothing /+\quad \quad$ NS $\quad$ NS $\quad$ NS

like-17 protein

ATP synthase

subunit beta

mitochondrial

ATP synthase

NS NS NS

NS

NS NS

$\varnothing /+\quad+/ \varnothing$

NS

subunit beta

Inflammatory response

Leukocyte

elastase inhibitor

$+/ \varnothing \quad \mathrm{NS} \quad+/ \varnothing$

NS

NS

$-1,22$

NS

NS $\quad-1,29$




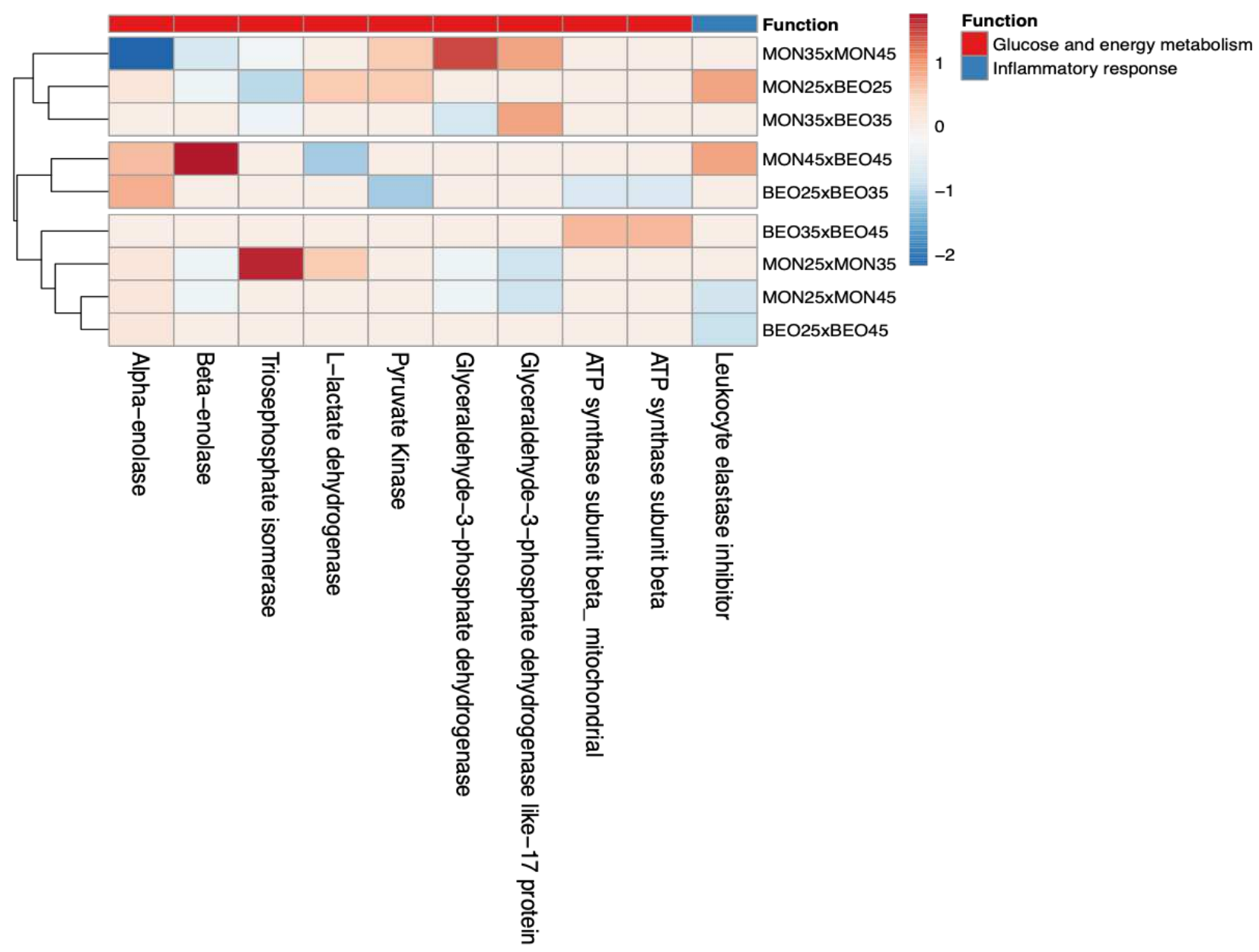

Figure 3. Heatmap of the differentially expressed proteins (ANOVA, $P \leq 0.05$ ) among the diets contending different starch levels and additives. Color-coded matrix showed the correlation coefficient of the SPOTS expression values. Each row and column represent one group and protein, respectively.

\section{Effects of feed additives and starch level on glucose and energy metabolism}

The expression values $(P \leq 0.05)$ (Table 4) were grouped from the hierarchical cluster analysis, and ordered by the homogeneity between the treatments tested. Animals fed with identical levels of starch, but submitted to different feed additives, showed differentiation for proteins that exercise functions in energy metabolism.

The animals fed with low starch in their diet (25\%) associated with BEO $\alpha$ increased expression of the proteins pyruvate kinase (EC 2.7.1.40), beta-enolase (EC 4.2.1.11), triosephosphate isomerase (EC 5.3.1.1) and L-lactate dehydrogenase (EC 1.1.1.27) compared to those treated with monensin; both proteins are enzymes catalyzing the synthesis of pyruvate, which is responsible for the degradation of carbohydrates. The highest level of starch tested (45\%) promoted the greater synthesis of L-lactate dehydrogenase (EC 1.1.1.27), fructose-bisphosphate aldolase (EC 4.1.2.13) and 
277 phosphoglycerate mutase (EC 5.4.2.4); it is noted that the intermediate starch level showed a higher 278 expression of triosephosphate isomerase (EC 5.3.1.1) and glyceraldehyde-3-phosphate dehydrogenase 279 (EC 1.2.1.12). Thus, the tested range shows a greater expression of glycolysis intermediates when 280 using BEO $\alpha$ (Figure 4). As demonstrated by Thomas, Webb, Ghimire, Blair, Olson, Fenske \& Scaria 281 (2017), the effect of monensin is more evident in the rumen, mainly in the diversity of microorganisms, 282 but a proportion below $10 \%$ results in post-ruminal action, corroborating the hypothesis that antibiotic 283 additives have a limited effect on the microbiota and intestinal fermentation of ruminants.

284 Protein expression differs depending on the starch levels in the diet $(P \leq 0.05)$; the cluster 285 analysis shows differentiation in the profile of the identified proteins involved in energy metabolism 286 (Figure 3), but the effect is greater when contrasting starch levels of $25 \%$ vs. $35 \%$ and $35 \%$ vs. $45 \%$, 287 mainly when using monensin as a feed additive. It is important to note that this was not observed when 288 assessing the range of levels (25\% vs. $45 \%)$, but there was a greater expression of proteins involved in 289 inflammatory responses (Figure 3), a fact that is attributed to the greater increase in carbohydrate in 290 the diets, which may have contributed to the lower expression of proteins associated with energy 291 metabolism. 


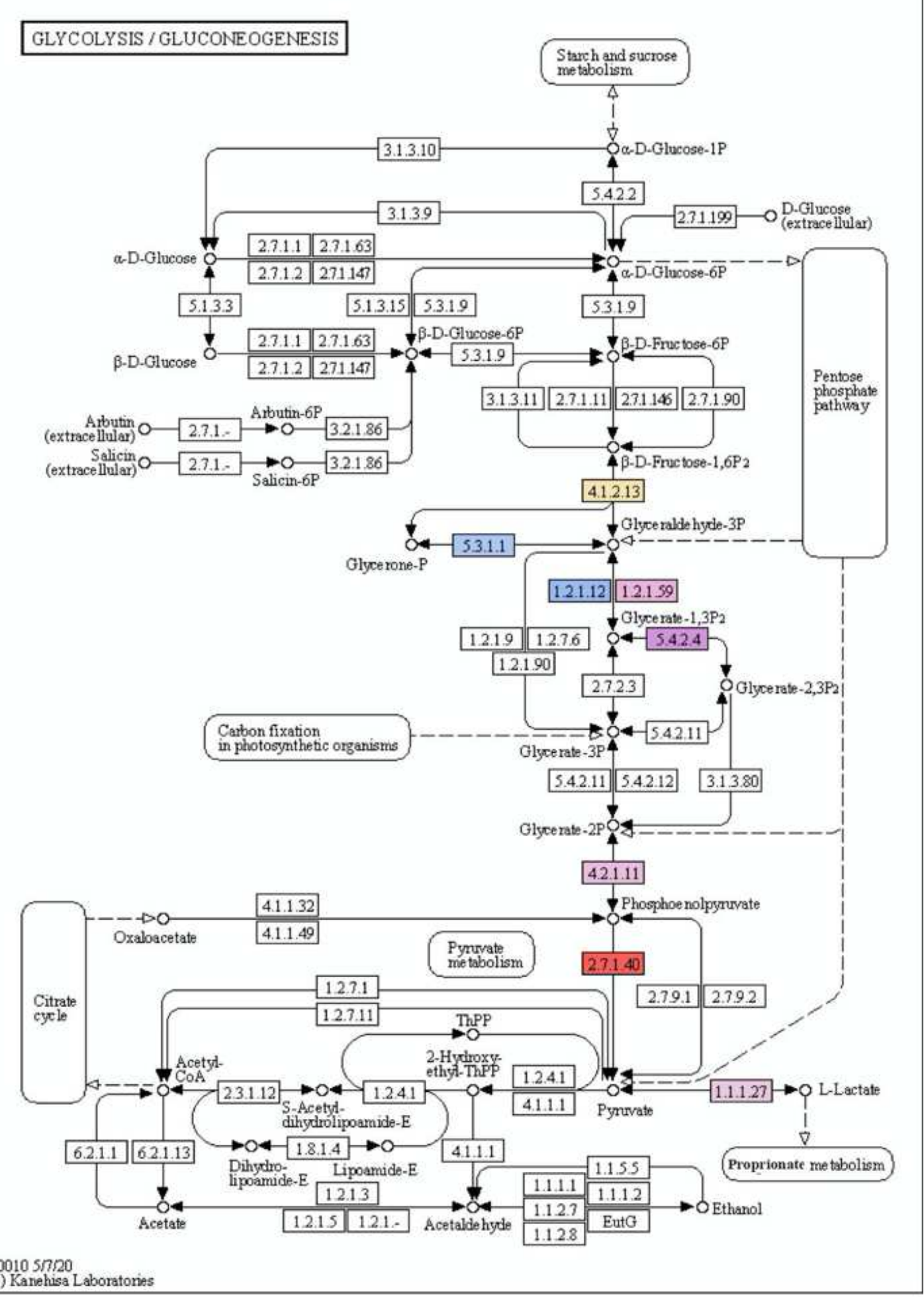

Figure 4. Expression protein profile encoding enzymes in glycolysis and gluconeogenesis pathway.

KEGG key: EC 4.1.2.13: Fructose-bisphosphate aldolase; EC 5.3.1.1: Triosephosphate isomerase; EC 1.2.1.12: Glyceraldehyde-3-phosphate dehydrogenase; EC 1.2.1.59: Glyceraldehyde-3-phosphate dehydrogenase like-17 protein; EC 5.4.2.4: Phosphoglycerate mutase; EC 4.2.1.11 Beta-enolase; EC 2.7.1.40 Pyruvate Kinase; EC 1.1.1.27 L-lactate dehydrogenase.

In view of the different feeding strategies, key enzymes were identified in the degradation of carbohydrates in the large intestine of cattle. Fructose-bisphosphate aldolase (ALDOB), an enzyme 
301 that converts fructose-1,6-bisphosphate to fructose 6-phosphate catalyzed by Triosephosphate 302 isomerase (TPI), is a precursor of glyceraldehyde-3-phosphate (GA3P), which is acted upon by the 303 glyceral enzyme 3-phosphate dehydrogenase (GAPDH) during glycolysis. Alpha-enolase (ENO1) and 304 beta-enolase (ENO3) are isoforms of enolase that are involved in Step 4 of glycolytic metabolism. 305 Phosphoglycerate mutase (PGM) is a catalytic enzyme that converts 3-phosphoglycerate to 2306 phosphoglycerate, and finally pyruvate kinase (PKM), which synthesizes pyruvate in the last step of 307 glycolysis. In ruminants, a high concentration of starch enables the fermentation of carbohydrates in 308 the cecum with lactate production, which increases glucose metabolism in the intestine observed 309 expression of the enzyme L-lactate dehydrogenase and its isoforms L-lactate dehydrogenase B and L310 lactate dehydrogenase A, which are responsible for the synthesis of lactate from pyruvate.

\section{Inflammatory response}

313 In the protein SPOTS of groups $25 \mathrm{BEO} \alpha$ and $45 \mathrm{BEO} \alpha$, in relation to those fed MON, there 314 was an absence in the expression of leukocyte elastase inhibitor, which is a serine protease inhibitor 315 that is essential in the regulation of inflammation responses, and which limits the activity of 316 inflammatory caspases [29]. When comparing $25 \%$ vs. $45 \%$ of starch in the diet, regardless of the type 317 of additive used, there was a greater expression of this protein, corroborating with previous studies, 318 which demonstrate that inflammatory injuries are caused by the increased use of concentrate in diets $319[30,31]$.

\section{Conclusions}

To verify the differential expression of the cecal proteome in cattle, our results show that the

323 blend of essential oils associated with $\alpha$-amylase, incorporated as a feed additive for beef cattle, 324 increased the expression of enzymes related to carbohydrate degradation, participated in glycolysis 325 and gluconeogenesis and reduced the inflammatory response when compared to monensin as a feed 
additive. Conversely, higher concentrations of starch reduced the expression of proteins involved in energy metabolism, and increased the expression of inflammatory responses.

\section{Acknowledgments}

The authors gratefully acknowledge support from the Bioanalytical and Metalloproteomics

Laboratory, Coordenação de Aperfeiçoamento de Pessoal de Nível Superior - Brazil (CAPES) and DSM Nutritional Products.

\section{Author's contributions}

LR designed and performed the experiment, analyzed samples and datas and wrote the manuscript.VC and AP designed and performed the experiment. MB, JA, AA and RM analyzed samples and datas. DM, JV and PP designed, supervised and analyzed samples and datas. All authors helped to revise, read and approved the final version of the manuscript.

\section{Funding}

This study was financed in part by the Coordenação de Aperfeiçoamento de Pessoal de Nível 342 Superior - Brazil (CAPES) - Finance Code 001 and the authors thank the DSM Nutritional Products 343 by financial support.

Availability of data and materials

348 Ethics approval and consent to participate

The experiment was carried out according to the standards issued by the National Council for

350 Animal Experimentation Control - CONCEA, and approved by the Ethics and Use of Animals 
351 Committee of the Universidade Estadual Paulista - UNESP, Botucatu -SP, under protocol $n^{\circ}$ $3520107 / 2019$.

354 Consent for publication

All authors provide their consent to this publication.

\section{Competing interests}

The authors declare that they have no conflicts of interest.

\section{Authors details}

$361{ }^{1}$ São Paulo State University (UNESP), School of Veterinary Medicine and Animal Science, 362 Botucatu, São Paulo, Brazil.; ${ }^{2}$ DSM Nutritional Products SA, São Paulo, Brazil.; ${ }^{3}$ University of São 363 Paulo (USP), Bauru School of Dentistry, Bauru, São Paulo, Brazil; ${ }^{4}$ University of Nebraska (UNL), 364 Department of Biochemistry, Lincoln, United States of America; ${ }^{5}$ São Paulo State University, 365 UNESP, College of Technology and Agricultural Sciences, Dracena, São Paulo, Brazil; ${ }^{6}$ São Paulo 366 State University (UNESP), Institute of Biosciences, Botucatu, São Paulo, Brazil.

\section{References}

369 1. Brake DW, Swanson KC. RUMINANT NUTRITION SYMPOSIUM: Effects of postruminal flows 370 of protein and amino acids on small intestinal starch digestion in beef cattle. J Anim Sci. 2018;96:739371 50. Available from: https://academic.oup.com/jas/advance-article/doi/10.1093/jas/skx058/4827744

372 2. Allen MS, Bradford BJ, Oba M. BOARD-INVITED REVIEW: The hepatic oxidation theory of the 373 control of feed intake and its application to ruminants. J Anim Sci. 2009;87:3317-34. Available from: 374 https://academic.oup.com/jas/article/87/10/3317-3334/4563378

375 3. Reynolds CK, Maltby SA. Regulation of Nutrient Partitioning by Visceral Tissues in Ruminants. J 
377 https://academic.oup.com/jn/article/124/suppl_8/1399S/4730462

378 4. Lozano O, Theurer CB, Alio A, Huber JT, Delgado-Elorduy A, Cuneo P, et al. Net absorption and 379 hepatic metabolism of glucose, L-lactate, and volatile fatty acids by steers fed diets containing 380 sorghum grain processed as dry-rolled or steam-flaked at different densities. J Anim Sci. 381 2000;78:1364. Available from: https://academic.oup.com/jas/article/78/5/1364-1371/4668495

382 5. National Academies of Sciences, Engineering, and Medicine - NASCEM. Nutrient Requirements 383 of Beef Cattle - NRBC. 8th ed. Washington, D.C.: National Academies Press; 2016. Available from: 384 http://www.nap.edu/catalog/19014

385 6. Silva FRN, Pereira AD, Baptista DP, Pereira MU, Spisso BF, Gigante ML, et al. Monensin residues 386 in the production of Minas Frescal cheese: Stability, effects on fermentation, fate and physicochemical 387 characteristics of the cheese. Food Res Int. 2020;137:109440. Available from: 388 https://linkinghub.elsevier.com/retrieve/pii/S0963996920304658

7. Meyer NF, Erickson GE, Klopfenstein TJ, Greenquist MA, Luebbe MK, Williams P, et al. Effect 390 of essential oils, tylosin, and monensin on finishing steer performance, carcass characteristics, liver 391 abscesses, ruminal fermentation, and digestibility1. J Anim Sci. 2009;87:2346-54. Available from: 392 https://academic.oup.com/jas/article/87/7/2346-2354/4731227

393 8. Meschiatti MAP, Gouvêa VN, Pellarin LA, Batalha CDA, Biehl M V, Acedo TS, et al. Feeding the 394 combination of essential oils and exogenous $\alpha$-amylase increases performance and carcass production 395 of finishing beef cattle1. J Anim Sci. 2019;97:456-71. Available from: 396 https://academic.oup.com/jas/article/97/1/456/5142563

397 9. Toseti LB, Goulart RS, Gouvêa VN, Acedo TS, Vasconcellos GSFM, Pires A V., et al. Effects of a 398 blend of essential oils and exogenous $\alpha$-amylase in diets containing different roughage sources for 
399 finishing beef cattle. Anim Feed Sci Technol. 2020;269:114643. Available from: 400 https://linkinghub.elsevier.com/retrieve/pii/S0377840120305472

401 10. Harmon DL, Yamka RM, Elam NA. Factors affecting intestinal starch digestion in ruminants: A 402 review. Can J Anim Sci. 2004;84:309-18. Available from: 403 http://www.nrcresearchpress.com/doi/10.4141/A03-077

404 11. Huntington GB, Harmon DL, Richards CJ. Sites, rates, and limits of starch digestion and glucose 405 metabolism in growing cattle1. J Anim Sci. 2006;84:E14-24. Available from: 406 https://academic.oup.com/jas/article/84/suppl_13/E14/4776389

407 12. Moharrery A, Larsen M, Weisbjerg MR. Starch digestion in the rumen, small intestine, and hind 408 gut of dairy cows - a meta-analysis. Anim Feed Sci Technol. Elsevier B.V.; 2014;192:1-14. Available 409 from: http://dx.doi.org/10.1016/j.anifeedsci.2014.03.001

410 13. Westreicher-Kristen E, Robbers K, Blank R, Tröscher A, Dickhoefer U, Wolffram S, et al. 411 Postruminal digestion of starch infused into the abomasum of heifers with or without exogenous 412 amylase administration. J Anim Sci. 2018;96:1939-51. Available from: 413 https://academic.oup.com/jas/article/96/5/1939/4958201

414 14. Owens FN, Zinn RA, Kim YK. Limits to Starch Digestion in the Ruminant Small Intestine1,2. J 415 Anim Sci. 1986;63:1634-48. Available from: https://academic.oup.com/jas/article/63/5/1634$416 \quad 1648 / 4662251$

417 15. Huntington GB. Starch utilization by ruminants: from basics to the bunk. J Anim Sci. 1997;75:852. 418 Available from: https://academic.oup.com/jas/article/75/3/852-867/4637334

419 16. Lohrenz A-K, Duske K, Schönhusen U, Losand B, Seyfert HM, Metges CC, et al. Glucose 420 transporters and enzymes related to glucose synthesis in small intestinal mucosa of mid-lactation dairy 421 cows fed 2 levels of starch. J Dairy Sci. 2011;94:4546-55. Available from: 
422 https://linkinghub.elsevier.com/retrieve/pii/S0022030211004668

423 17. Mills JAN, France J, Ellis JL, Crompton LA, Bannink A, Hanigan MD, et al. A mechanistic model 424 of small intestinal starch digestion and glucose uptake in the cow. J Dairy Sci. American Dairy Science 425 Association; 2017;100:4650-70. Available from: 426 http://linkinghub.elsevier.com/retrieve/pii/S0022030217302758

427 18. Pinto ACJ, Millen DD. Nutritional Recommendations and Management Practices Adopted By 428 Feedlot Cattle Nutritionists: the 2016 Brazilian Survey. Can J Anim Sci. 2018;1-46.

429 19. Hoover WH. Digestion and Absorption in the Hindgut of Ruminants. J Anim Sci. 1978;46:1789430 99. Available from: https://academic.oup.com/jas/article/46/6/1789-1799/4699332

431 20. Siciliano-Jones J, Murphy MR. Production of Volatile Fatty Acids in the Rumen and Cecum-Colon 432 of Steers as Affected by Forage: Concentrate and Forage Physical Form. J Dairy Sci. 1989;72:485-92. 433 Available from: https://linkinghub.elsevier.com/retrieve/pii/S002203028979130X

434 21. Fox D., Tedeschi L., Tylutki T., Russell J., Van Amburgh M., Chase L., et al. The Cornell Net 435 Carbohydrate and Protein System model for evaluating herd nutrition and nutrient excretion. Anim 436 Feed Sci Technol. 2004;112:29-78. Available from: 437 https://linkinghub.elsevier.com/retrieve/pii/S0377840103002979

438 22. McIntosh FM, Williams P, Losa R, Wallace RJ, Beever DA, Newbold CJ. Effects of Essential Oils 439 on Ruminal Microorganisms and Their Protein Metabolism. Appl Environ Microbiol. 2003;69:5011440 4. Available from: https://aem.asm.org/content/69/8/5011

441 23. Doumas BT, Bayse DD, Carter RJ, Peters T, Schaffer R. A candidate reference method for 442 determination of total protein in serum. I. Development and validation. Clin Chem. 1981;27:1642-50. 443 Available from: http://www.ncbi.nlm.nih.gov/pubmed/6169466 
444 24. Santos FA, Lima PM, Neves RCF, Moraes PM, Pérez CA, Silva MOA, et al. Metallomic study on 445 plasma samples from Nile tilapia using SR-XRF and GFAAS after separation by 2D PAGE: Initial 446 results. Microchim Acta. 2011;173:43-9.

447 25. Neves RCF, Lima PM, Baldassini WA, Santos FA, Moraes PM, Castro GR, et al. Fracionamento 448 de cobre em proteínas do plasma, músculo e fígado de tilápia do Nilo. Quim Nova. 2012;35:493-8.

449 26. Moraes PM, Santos FA, Padilha CCF, Vieira JCS, Zara LF, De M. Padilha P. A preliminary and 450 qualitative metallomics study of mercury in the muscle of fish from amazonas, Brazil. Biol Trace Elem $451 \quad$ Res. 2012;150:195-9.

452 27. Silva FA, Cavecci B, Baldassini WA, Lima PM, Moraes PM, Roldan PS, et al. Selenium 453 fractionation from plasma, muscle and liver of Nile tilapia (Oreochromis niloticus). J Food Meas 454 Charact. 2013;7:158-65.

455 28. Shevchenko A, Tomas H, Havli J, Olsen J V, Mann M. In-gel digestion for mass spectrometric 456 characterization of proteins and proteomes. Nat Protoc. 2006;1:2856-60. Available from: 457 http://www.nature.com/articles/nprot.2006.468

458 29. Choi YJ, Kim S, Choi Y, Nielsen TB, Yan J, Lu A, et al. SERPINB1-mediated checkpoint of 459 inflammatory caspase activation. Nat Immunol. 2019;20:276-87. Available from: 460 http://www.nature.com/articles/s41590-018-0303-z

461 30. Liu J, Xu T, Zhu W, Mao S. High-grain feeding alters caecal bacterial microbiota composition and 462 fermentation and results in caecal mucosal injury in goats. Br J Nutr. 2014;112:416-27. Available 463 from: https://www.cambridge.org/core/product/identifier/S0007114514000993/type/journal_article

464 31. Chang G, Ma N, Zhang H, Wang Y, Huang J, Liu J, et al. Sodium Butyrate Modulates Mucosal 465 Inflammation Injury Mediated by GPR41/43 in the Cecum of Goats Fed a High Concentration Diet. 466 Front Physiol. 2019;10. Available 
467 https://www.frontiersin.org/article/10.3389/fphys.2019.01130/full 
Figures

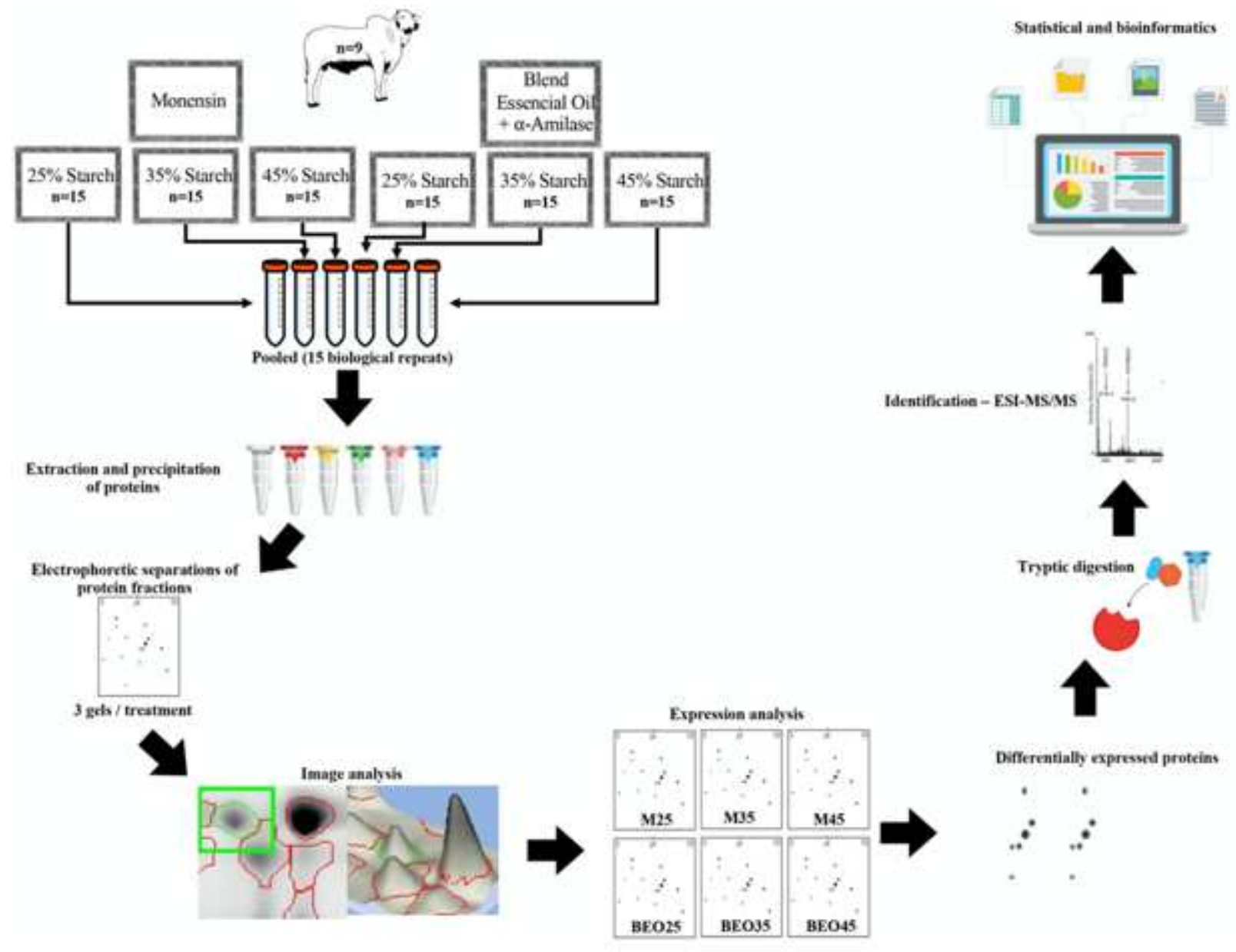

Figure 1

Graphical abstract 


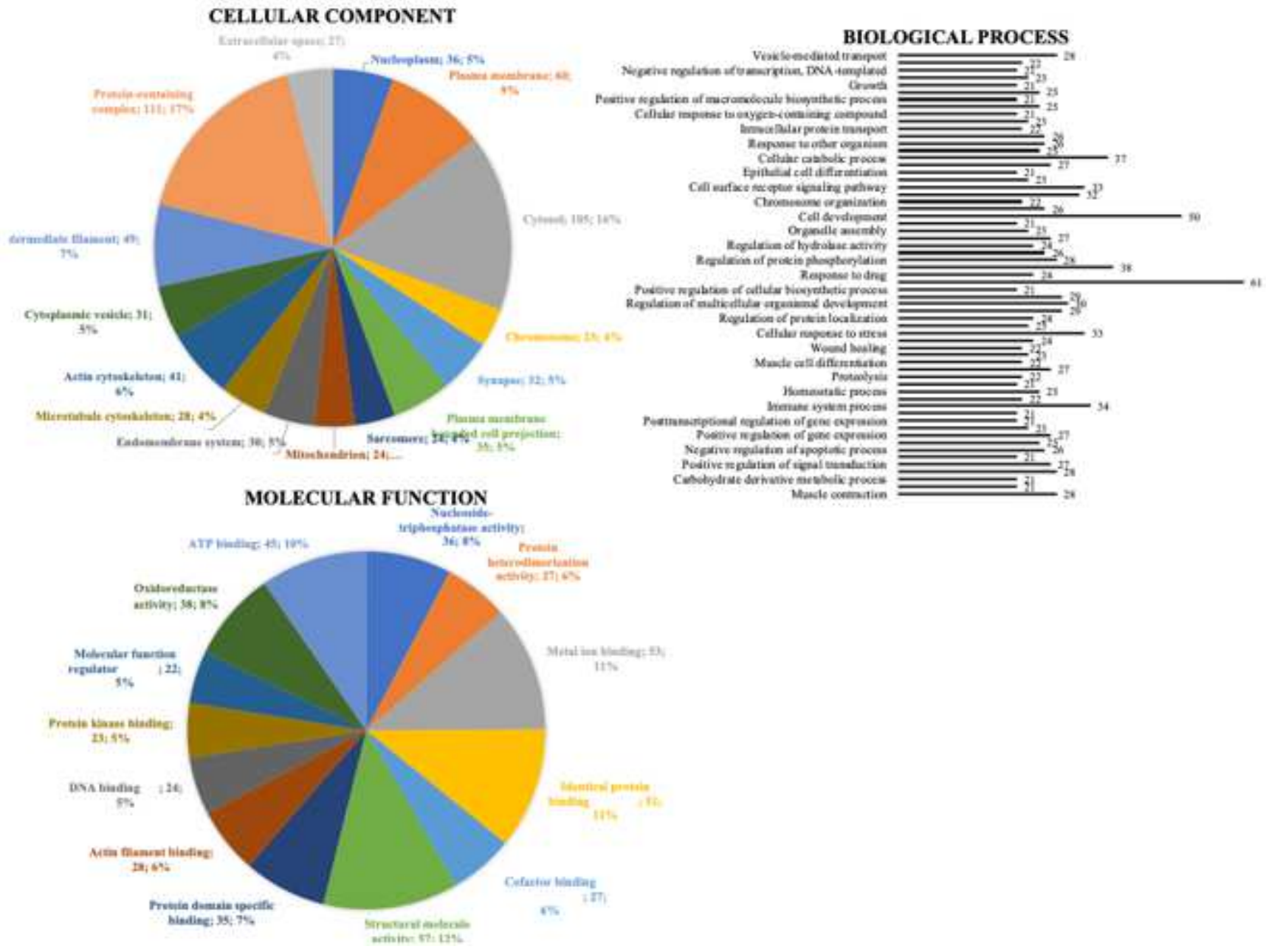

\section{Figure 2}

Classification of the proteins sequences found in beef cattle cecum proteome using OMICSBOX software analysis (Blast2GO). 


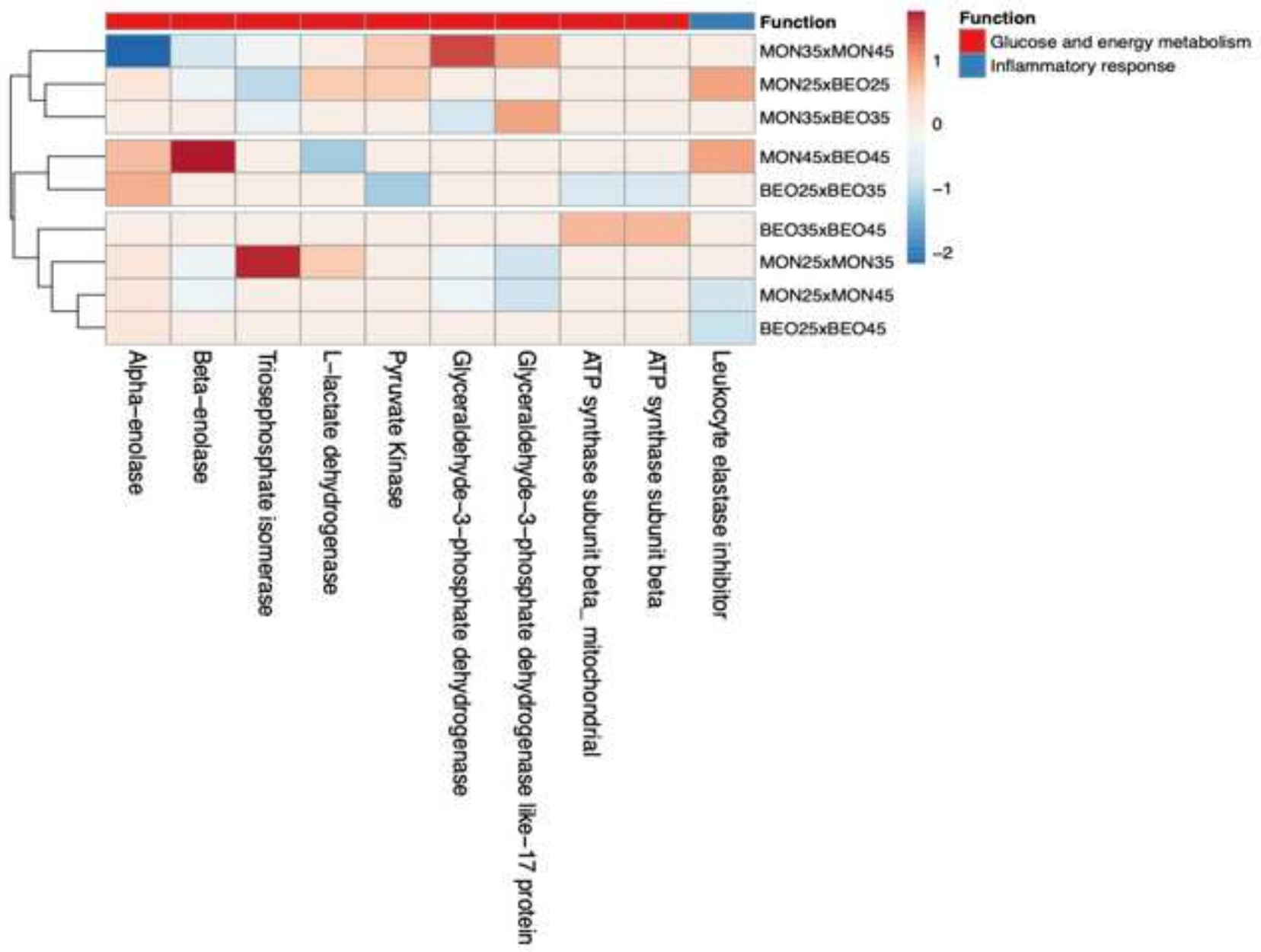

\section{Figure 3}

Heatmap of the differentially expressed proteins (ANOVA, ) among the diets contending different starch levels and additives. Color-coded matrix showed the correlation coefficient of the SPOTS expression values. Each row and column represent one group and protein, respectively. 


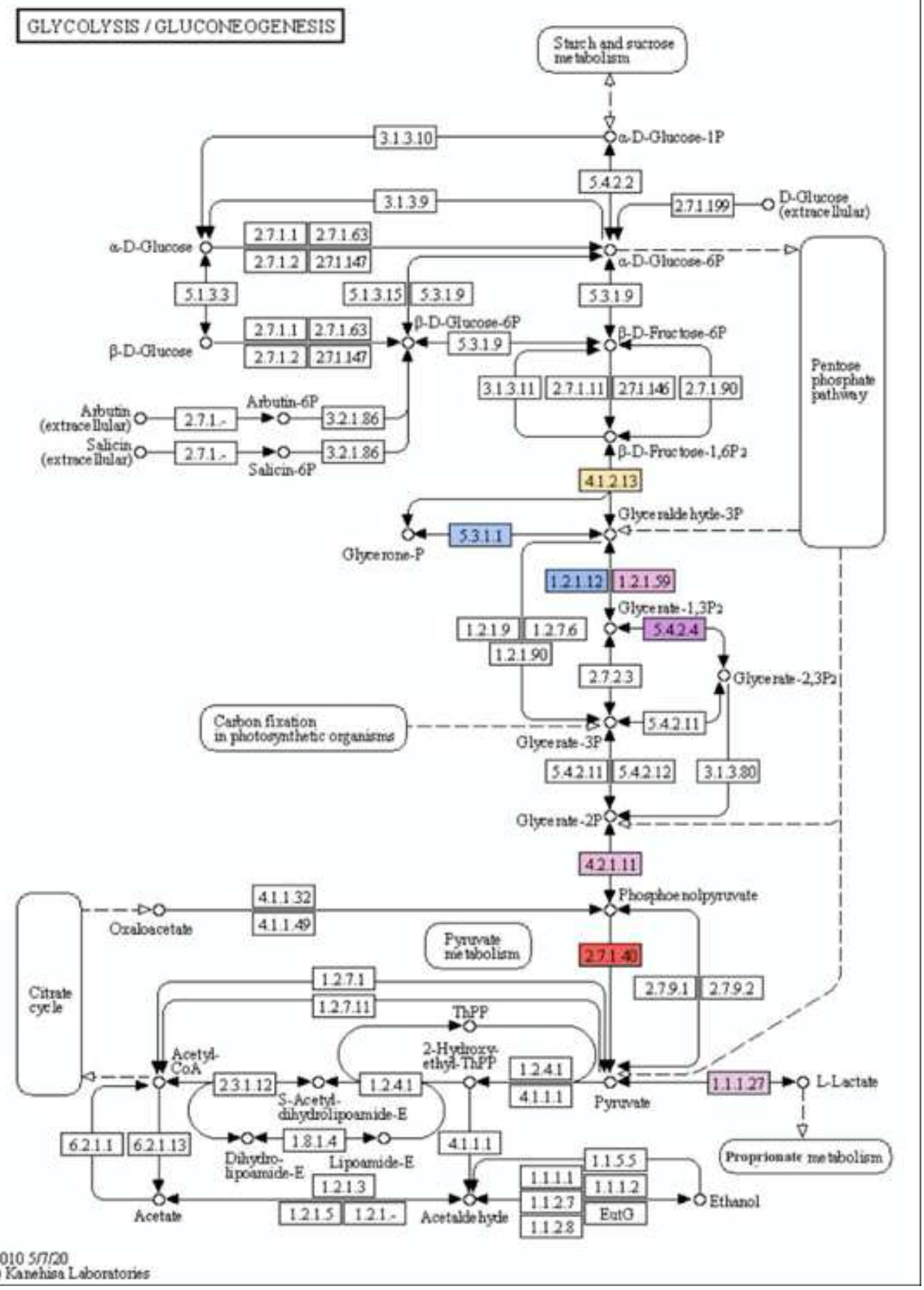

Figure 4

Expression protein profile encoding enzymes in glycolysis and gluconeogenesis pathway. KEGG key: EC 4.1.2.13: Fructose-bisphosphate aldolase; EC 5.3.1.1: Triosephosphate isomerase; EC 1.2.1.12: Glyceraldehyde-3-phosphate dehydrogenase; EC 1.2.1.59: Glyceraldehyde-3-phosphate dehydrogenase like-17 protein; EC 5.4.2.4: Phosphoglycerate mutase; EC 4.2.1.11 Beta-enolase; EC 2.7.1.40 Pyruvate Kinase; EC 1.1.1.27 L-lactate dehydrogenase. 